Primljeno: 01. 10. 2020.

Prihvaćeno za štampu: 29. 12. 2020.

\author{
Dr. sc. Nusreta Kepeš, vanredni profesor \\ Univerzitet u Bihaću \\ Islamski pedagoški fakultet \\ Email:nusretakepes@yahoo.com
}

\title{
MJESTO I ULOGA SOCIJALNIH PEDAGOGA U ODGOJNO- OBRAZOVNIM I USTANOVAMA SOCIJALNE SKRBI
}

\section{Sažetak}

Nove drustvene okolnosti kao i problemi s kojima se društvo suočava kada su u pitanju djeca i mladi s poremé́ajima u ponašanju, sve više namé́u potrebu da se istraže uzroci takvog ponašanja te elaboriraju socio-pedagoške intervencije i ponude modeli socijalne integracije. Uloga socijalnog pedagoga je u ovoj problematici jako važna naročito $u$ području dijagnostike, prevencije i tretmana poremé́aja u ponašanju. U zemljama EU, kao $i$ zemljama u regiji zanimanje socijalnog pedagoga je prepoznato $i$ uvršteno $u$ sistematizaciju radnih mjesta u velikom broju odgojno-obrazovnih, socijalnih, peneloških $i$ zdravstvenih institucija. U BiH situacija je znatno drugačija. Diplomirani socijalni pedagozi, ne samo da teže pronalaze posao, već imaju i problem polaganja stručnog ispita, jer se $u$ standardima $i$ normativima obrazovnih, socijalnih $i$ zdravstvenih ustanova rijetko spominje socijalni pedagog kao strucni saradnik. U posljednje vrijeme dolazi do pozitivnih promjena, tako da sada socijalnog pedagoga možemo vidjeti zaposlenog $u$ vrticima, centrima za socijalni rad, zdravstvenim ustanovama, komunama, domovima za starije osobe, domovima za djecu bez. roditeljskog staranja, produřenom boravku u osnovnim školama i kao pomocnike u nastavi, uz obavezu polaganja pedagoške grupe predmeta. Iako su ovo mali pomaci, oni su jako značajni u profiliranju ovog poziva. Fakulteti koji obrazuju ovaj kadar $i$ udru气̌enja socijalnih pedagoga mogu dati veliki doprinos na način da studenti provedu veci broj prakticnih sati $u$ institucijama tokom studiranja, medijski promoviraju drustveni i humani ugled struke te lobiraju kod nadležnih ministarstava da se zakonski utemelji profil socijalnog pedagoga kao stručnog saradnika u obrazovanju, socijalnom radu, zdravstvu $i$ drugim dr:̌avnim institucijama. Dr:̧avna politika, takoder, može utjecati na zapošljavanja ovog kadra u javnim i dř̌annim slušbama, 
stoga je bitno da u kereiranju politike, zakona, standarda $i$ normativa kao $i$ sistematizacije radnih mjesta u rąličitim institucijama, ovo zanimanje bude uvrsteno. Ulaskom socijalnih pedagoga u timove i stručne sluð̌be u velikoj mjeri će doprinijeti da se stanje u drustun poboljša, narocito kada je u pitanju nasilje nad (i medu) djecom $i$ mladima. Imajuci u vidu da je socijalna pedagogija u BiH tek u povojima, u budućnosti se ǒ́ekuje snažna afirmacija ovog poziva koja ima pomagački karakter. Ovaj je rad usredotočen na primjenu koncepta socijalnih profesionalnih granica na praktičnom, kao i teorijskom i naucnom nivou discipline socijalne pedagogije

Ključne riječi: Socijalna pedagogija, kompetencije socijalnih pedagoga, pedagoška $i$ socijalna dimeñija profesije socijalnib pedagoga

\section{UVOD}

Socijalna pedagogija je grana pedagogije, a već desetljeće se promatra kao akademska disciplina koja pedagoškim stajalištima naglašava promociju ljudskog dostojanstva, dušebrižništva, inkluzije, integracije i života pojedinca ili grupa u zajednicama. Većina autora navodi kako se socijalna pedagogija prema drugim društvenim disciplinama smatra subdisciplinom edukacijskih znanosti ili samostalnom disciplinom unutar društvenih znanosti (Rauschenbach, 1987; Hamalainen, 1999, prema Žižak, 2001). Kao opća znanost se izdvaja iz okvira ostalih srodnih ili manje srodnih društveno-humanističkih disciplina po načinu rješavanja problema jer ih izučava i analizira iz više znanstvenih grana. Međutim dvije orijentacije su dominantne ( pedagoška i socijalna) o čemu svjedoči i sam naziv koji je vidljiv u imenu profesije (Hallstedt and Hogstrom, 2005; Kornbeck, 2013; Ucar, 2013). Pedagoška dimenzija je usmjerena na prevenciju i formiranje poželjnih odgojnih ponašanja svih dobnih skupina $u$ obrazovanju (formalnom, neformalnom, informalnom i cjeloživotnom). Socijalna orijentacija se pripisuje detekciji, korektivnim, resocijalizacijskim i drugim vidovima socijalne podrške koji tretiraju nepoželjne oblike ponašanja i probleme osjetljivih kategorija ljudi.

Socijalna pedagogija, u akademskoj domeni, obrazuje kadar socijalnih pedagoga koji spada u skupinu pomažućih poziva s više složenih polivalentnih funkcija. Upravo je i cilj ovog rada definiranje kompetencija socijalnih pedagoga $u$ različitim poljima djelovanja kao 
što je obrazovanje, socijalni sektor, sektor pravosuđa i zdravstva. Socijalni pedagozi rade na prevenciji, resocijalizaciji, korekturi, suportivnoj i socioterapiji s pojedincima ili grupama u svim razvojnim fazama. Poseban fokus je usmjeren na mlade s poteškoćama u socijalnoj integraciji.

Također, želimo istaknuti svrhu rada koji ima za cilj prikazati interdiciplinarnost poziva socijalnog pedagoga, kao stručnog saradnika, koji se ne poistovjećuje s drugim zanimanjima kao što su pedagog ili psiholog, socijalni radnik, pravnik, rehabilitator itd, već on ima svoje mjesto i ulogu, kako u nomenklaturi klasifikacije zanimanja (KZBiH08), tako i u sistematizaciji radnih mjesta. ${ }^{1}$

Podaci prikazani u ovom radu temelje se na informacijama koje su prikupljane u: publikacijama, odnosno u znanstveno-teoretskoj raspravi u ovdje tematiziranom području, pretraživanju službenih webstranica institucija te zvaničnih statističkih podataka i analizom dostupnih univerzitetskih progama koji obrazuju kadar socijalnih pedagoga i srodnih zanimanja.

\section{Kratak pregled općeg istraživanja razvoja socijalne pedagogije kroz historiju}

Počevši od 18. stoljeća, kada je formirana škola klasičnog tipa, znanstvenici, nastavljaju rješavati probleme socijalnog obrazovanja koji je postao zahtjev vremena. Prema Schmidtu (1981), godina početka bavljenja socijalnom pedagogijom je 1899. Naime, njemački učitelj Paul Natorp je zadaću i ciljeve socijalne pedagogije objavio u „Socijalno-pedagoškoj teoriji oblikovanja odgoja volje na osnovi zajednice" (Previšić, Prgomet 2007). Glavni cilj ove teorije je bio da se problemi tadašnjeg društva mogu promijeniti putem obrazovanja (Bouillet, Uzelac, 2007). Potreba za socijalnom pedagogijom se pojavila na prijelazu iz 19. u 20. stoljeće u vrijeme kad je Njemačka bila socijalno i politički podijeljena. Ideju da se ista utemelji u znanost razvio je Herman Nohl (1919) profesor filozofije i pedagogije na Sveučilištu u Göttingenu. Nohl je u svojim radovima zagovarao socijalnu pedagogiju. U posebnom petom svesku „Priručnika

\footnotetext{
${ }^{1} \mathrm{KZBiH}-08$ se zasniva na usvojenoj verziji Međunarodne standardne klasifikacije zanimanja 2008 (oznaka: ISCO -08), koja je usvojena u decembru 2007.
} 
pedagogije” (Handbuch der Pädagogik 1925-1933) objavio je naslov „Socijalna pedagogija” (Sozialpädagogik). U njemu je istakao da se socijalna pedagogija definira kao znanosti o odgoju koja se u prvom redu bavi problemima obiteljskog i javnog odgoja čije su pravne odredbe definirane Državnim zakonom o dobrobiti mladeži iz 1922. godine“ (Previšić, 2007; Uhlendorff, 2012). Drugi svjetski rat je donio stagnaciju u izučavanju socijalne pedagogije, međutim njeno propitivanje se nastavilo u prvim desetljećima 20. stoljeća kada se vodila opširna rasprava oko teorijskih pitanja i njene utemeljenosti kao nauke (Thiersch, 1996). Od brojnih savremenih pristupa izdvajamo Klausa Mollenhauera i Hansa Thierscha koji socijalnu pedagogiju zagovaraju kao granu pedagogije, odnosno odgojnu znanost ( Engelke, 2002). Winkler (1993) i Niemeyera (1998) ističu da socijalna pedagogija kao akademska nauka treba da ima identitet kao profesija ili disciplina, da ima ciljeve, zadaće, svoj predmet, sadržaje, spoznajne metode i teorije te da mora biti omeđena predmetima koji su za jednu profesiju ili disciplinu obavezni. Bouillet i Uzelac, (2007) navode da sadržaji socijalne pedagogije idu u dva smjera: prvi obuhvata socijalnu pedagogiju kao zasebno odgojno područje, nastalo kao odgovor na probleme društva, dok drugi smjer definira socijalnu pedagogiju kao odgoj za moralno ponašanje.

Historijski gledano „najbogatiju praksu sveučilišnog usavršavanja socijalnih pedagoga nalazimo upravo u Njemačkoj. Tako odjeli ili odsjeci za socijalnu pedagogiju djeluju na najmanje 15 visokih škola koje čine sastavni dio različitih sveučilišta“" (Bouillet, D. 2005). Razvoj socijalne pedagogije se paraleno odvijao i u drugim zemljama Evrope tako da je u sklopu edukacijsko-rehabilitacijskih znanosti ponajviše prepoznatljiv u Mađarskoj dok se socijalna pedagogija u kontekstu socijalnog rada izučava u Austriji i Finskoj. U Slovačkoj je u sklopu Odjela za pedagogiju i socijalni rad pedagoških fakulteta. U Češkoj, Nizozemskoj, Poljskoj i Sloveniji socijalna pedagogija se u pravilu razvija na pedagoškim fakultetima, a u Belgiji, Latviji i Litvi na pedagoško-psihološkim fakultetima. Spomenut ćemo da se u Francuskoj, Luksemburgu, Švicarskoj, Irskoj i Danskoj socijalni pedagozi (najčešće pod nazivom specijalni odgajatelji) školuju na razini viših stručnih škola koje nemaju sveučilišni i znanstveni karakter (Poldrugač, Z., 1999). Znanstvena utemeljenost socijalne pedagogije u Republici Hrvatskoj se razvija pri Odsjeku za poremećaje u ponašanju 
Edukacijsko-rehabilitacijskog fakulteta Sveučilišta u Zagrebu, a u Srbiji pri Odeljenju za prevenciju i tretman poremećaja ponašanja. U Bosni i Hercegovini kadar socijalnih pedagoga se obrazuje na tri visokoškolske institucije - Tuzli, Zenici i Bihaću. U Tuzli pri Edukacijsko-rehabilitacijskom fakultetu na Odsjeku poremećaji u ponašanju, u Zenici na Islamskom pedagoškom fakultetu pri Odsjeku za socijalnu pedagogiju i Bihaću čiji je isti osnivač na Odsjeku za socijalnu pedagogiju i duhovnu skrb. Dakle u zemljama Evrope i regije, socijalna pedagogija kao znanstvena disciplina se pozicionirala u okviru:

a) edukacijsko-rehabilitacijskih znanosti;

b) socijalnih znanosti (socijalnog rada);

c) humanističkih (pedagoško-psiholoških) znanosti.

Iz rečenog možemo zaključiti da se Socijalna pedagogija bavi socijalnim i edukacijskim teorijama te ih kombinira podrazumijevajući njihovo međusobno prožimanje. Dakle, prilično je teško reći pripada li socijalna pedagogija porodici socijalnih ili edukacijskih znanosti. Naime, interdisciplinarnost socijalne pedagogije očituje se u njenom studijskom obrazovanju, ali i u profesionalnom radu pri čemu socijalni pedagozi moraju vladati osnovnim znanjima iz pedagogije, psihologije, psihijatrije, sociologije i slično. Povećanje interdisciplinarnosti dovodi do mogućnosti djelovanja u širokom socijalnom polju, ali i do opasnosti od gubitka identiteta struke (Mikšaj-Todorović i Buđanovac, 1999). Naime, ako se struka bavi tako širokim područjem, teško je precizirati ko su socijalni pedagozi.

Područja djelovanja socijalne pedagogije mogu se prema Koboltu (1997) dijeliti na:

- pedagoško (povećanje općih kompetencija na planu odgoja obrazovanja);

- socijalno (razvoj sposobnosti za socijalnu integraciju i participaciju);

- korekcijsko (rješavanje problema i sukoba, zaštita i integracija) i

- terapeutsko (otklanjanje smetnji, osamostaljivanje, povećanje kvalitete života). 
Tuggener (1990), pak navodi da socijalni pedagozi rade na dvije razine. $\mathrm{Na}$ razini područja (rehabilitacije/integracije) i na razini korisnika. Naime radi se o pojedincima, grupama i zajednici koja na tim područjima imaju probleme ili su neizostavni dio procesa rješavanja problema. Socijalna pedagogija djeluje i u širem kontekstu, kao što je slučaj socio-kulturne animacije, obrazovanja o održivom razvoju, upravljanja kulturnom baštinom itd.

\section{Socijalna pedagogija kao znanost, praksa i profesija u Bosni i Hercegovini}

Prema Boehnischu (1993) socijalna pedagogija danas postaje dio socijalne infrastrukture pri čemu rad socijalnog pedagoga nema više samo funkciju pomoći u učenju i podršci korisnika, već ima i vlastite vrijednosne zadaće. Prvo razdoblje razvoja socijalnopedagoške profesije u Bosni i Hercegovini započinje 1993. godine kada se osniva Defektološki fakultet u Tuzli koji je kasnije promijenio ime $\mathrm{u}$ Edukacijsko rehabilitacijski fakultet. $\mathrm{Na}$ ovom fakultetu se 2005. godine oformio odsjek Poremećaji u ponašanju, gdje studenti, kada završe ovaj studijski odsjek, dobivaju zvanje diplomirani socijalni pedagog. Profil socijalnog pedagoga kao praktično zasnovane profesije se pokazao iznimno važnim jer su u BiH još uvijek ugrožena ljudska prava i narušeni principi socijalne pravde. Naime ova profesija je usmjerena na otklanjanje prepreka i osnaživanje ljudi u prevazilaženju teškoća i povećanju blagostanja. Potrebu za obrazovanjem profila socijalnih pedagoga prepoznao je i privatni Fakultet društvenih znanosti "Dr Milenko Brkić" koji je 2009. godine pokrenuo i Preddiplomski studij Socijalne pedagogije. Nastava na ovom odsjeku se odvija na tri cikulsa studija po sistemu $3+2+3$, što bi značilo da prvi ciklus studija traje 3 godine (180 ECTS), drugi ciklus je u trajanju od 2 godine (120 ECTS), a treći ciklus traje isto kao i prvi, 3 godine (180 ECTS).

Otvaranjem odsjeka socijalne pedagogija na drugim područjima $\mathrm{BiH}$ je postala realnost tako da se već ak. 2005/06. godine formira Odsjek za socijalnu pedagogiju čiji je osnivač Islamski pedagoški fakultet u Zenici. Odsjek traje četiri akademske godine, odnosno osam semestara. Ekspanziju doživljava pokretanjem II ciklusa, a u toku je izrada Elaborata o društveno-ekonomskoj opravdanosti i III ciklusa (doktorskog) studija. 
Samo dvije godine poslije, Islamski pedagoški fakultet u Bihaću 2011. godine je oformio Odsjek za socijalnu pedagogiju i duhovnu skrb. Konstrukcija ovakvog studijskog odsjeka intenzivira integriranost korpusa programskoga sadržaja čije su referentne nauke iz domena teologije, pedagogije, psihologije, defektologije, socijalnog rada, medicine i penologije. Utemeljenje duhovne skrbi je bazirano na duhovno-znanstvenoj socijalnoj pedagogiji kao najstarijoj i nakon Drugoga svjetskog rata dominantnoj socijalno-pedagoškoj školi. Odsjek Socijalne pedagogije i duhovne skrbi u Bihaću, predstavlja jedinstven spoj naučnih i duhovnih vrijednosti. U akad. 2017/2018. godini pokrenut je drugi ciklus, gdje studenti nakon završetka stiču zvanje magistra socijalne pedagogije ili magistra socijalne pedagogije i duhovne skrbi.

Modeli studijskih programa Socijalne pedagogije (i duhovne skrbi) u Zenici i Bihaću su dizajnirani i razvijeni u skladu s ESG-standardima i smjernicama za osiguranje kvaliteta u Evropskom području višeg obrazovanja (Standards and Guidelines for Quality Assurance in the European Higher Education Area). U tabeli broj. 1 definirani su sadržaji koji opisuju kvalifikaciju zanimanja socijalnog pedagoga.

Fakulteti koji obrazuju kadar socijalnih pedagoga pretežno su orijentirani na stjecanje specijalističkih znanja i kompetencija za rad u savjetovalištima, predškolskim ustanovama, osnovnim i srednjim školama, dječijim i đačkim domovima, centrima za socijalnu zaštitu, centrima za odgoj djece i omladine, dispanzerima i centrima za mentalno zdravlje, odgojnim domovima, državnim tužilaštvima, sudovima, odgojnim zavodima, kaznenim zavodima, okružnim zatvorima, policijskim stanicama, psihijatrijskim klinikama i istraživačkim centrima. U BiH vokacija socijalni pedagog uvrštena je u Standardnu klasifikaciju zanimanja u Federaciji BiH pod rednim brojem 235107.

Nažalost, u BiH ne postoji jedinstvena legislativa koja bi propisala normative i standarde stručnih radnika i saradnika profila socijalnog pedagoga. Tako npr. u Zakonu o predškolskom odgoju i obrazovanju Zeničko-dobojskog kantona socijalni pedagog je definiran kao stručni 
saradnik. $^{2}$ Ovaj profil nije prepoznat u drugim kantonima. Isti je slučaj i s Kantonom Sarajevo koji propisuje da u produženom boravku u osnovnoj školi može raditi socijalni pedagog, a u drugim kantonima ta uredba ne postoji. Neki kantoni kao što je slučaj Unsko-sanskog kantona propisuju da osobe s visokim obrazovanjem (240) ECTS bodova mogu biti angažirani kao pomoćnici u nastavi u radu s djecom s poteškoćama u razvoju uz uvjet da imaju položeno dopunsko pedagoško-psihološko i metodičko-didaktičko obrazovanje kao i dodatno stručno osposobljavanje ${ }^{3}$ (Član 41, Pravilnik o standardima za rad i pružanje usluga u ustanovama socijalne zaštite u F BiH). Službene novine 15/13, navode socijalnog pedagoga kao stručnog saradnika koji može da radi u ustanovama socijalne zaštite. Bez obzira što je jako minoran broj zaposlenih socijalnih pedagoga, kao i činjenica da na tim pozicijama rade osobe koje nemaju ni stručnih ni generičkih kompetencija, vrijedno je spomenuti nekoliko svijetlih primjera. Naprimjer, u Zeničko-dobojskom, Tuzlanskom, Unsko-sanskom i Kantonu Sarajevu unazad par godina omogućeno je osposobljavanje socijalnih pedagoga kroz volonterski i pripravnički staž. Tokom stažiranja, ovaj profil stručnjaka se pokazao iznimno potrebnim tako da su neke socijalne, obrazovne i zdravstvene ustanove, shodno svojim mogućnostima, izmijenile sistematizaciju radnih mjesta i zaposlile socijalne pedagoge. Uvjet za zapošljavanje je, svakako, položen stručni ispit koji je i zakonski obavezujući. Obaveza polaganja stručnog ispita socijalnih pedagoga se temelji na sljedećim zakonima: Zakon o srednjoj naobrazbi (Broj:6/04 i 7/05), članka 77, Zakon o osnovnom odgoju i naobrazbi (Broj: 6/04 i 7/05), članka 34, Zakon o predškolskom odgoju i naobrazbi ("Službene novine Tuzlanskopodrinjskog kantona", broj: 8/98 i Broj 6/04), članka 27, Zakona o radu ("Službene novine Federacije Bosne i Hercegovine", broj 43/99, 32/00 i 29/03) te Pravilnikom o polaganju stručnog ispita).

${ }^{2}$ Pedagoški standardi i normativi za predškolski odgoj i obrazovanje, član VI, SLUŽBENE NOVINE ZENIČKO-DOBOJSKOG KANTONA Broj 2 - strana 137, petak, 18. 2. 2011

${ }^{3}$ Pravilnik o odgoju i obrazovanju, praćenju i ocjenjivanju djece s teškoćama u razvoju u Unsko-sanskom kantonu, član 50 (Službeni glasnik Unsko-sanskog kantona, broj 15 - strana 1025 od 25. decembra 2015). 


\section{Komepetencije socijalnih pedagoga}

Kada govorimo o kompetencijama, sam termin možemo svesti na skup ponašanja, sposobnosti i znanja koja su potrebna za obavljanje radnih zadataka $\mathrm{u}$ profesionalnom $\mathrm{tj}$, radnom okruženju pojedinca $\mathrm{za}$ zanimanje za koje se obrazovao. Evropsko vijeće je 2002. godine predstavilo koncept ključnih kompetencija za život u 21. stoljeću koje treba da budu razvijene do kraja obaveznog školovanja i osnova su za daljnji razvoj u okviru cjeloživotnog učenja (Europska komisija, 2004). U Programu je i razrađen okvir od osam ključnih kompetencija i uz njih vezanih znanja, vještina i stavova: $\bullet$ Komunikacija na materinskom jeziku, $\cdot$ Komunikacija na stranom jeziku, •Matematička pismenost i osnovno poznavanje znanosti i tehnologije, - Digitalna kompetencija, -Kompetencija učiti-kako-učiti, -Interpersonalna i građanska kompetencija, •Poduzetništvo i •Kulturna ekspresija. „Europski okvir za ključne kompetencije“" usvojen je kao rezultat političkih pregovora Komisije i Parlamenta Evropske unije jer je zaključeno da upravo usvajanje ključnih kompetencija služi kao preduvjet za ostvarivanje ličnih ambicija pojedinca, aktivno sudjelovanje u različitim društvenim procesima te mogućnost zapošljavanja u društvu znanja (Jokić i sar, 2007).

Govoreći o socijalnim pedagozima, prema kriterijima Europskog ureda međunarodnih udruga socijalnih edukatora - AIEJI (2005), profesionalne kvalifikacije mogu se podijeliti na bazične i centralne kompetencije. Bazične kompetencije su (1) intervencijske kompetencije, (2) kompetencije evaluiranja i (3) kompetencije refleksije (samoprocjena). Centralne kompetencije obuhvataju (1) osobne i relacijske kompetencije; (2) socijalne i komunikacijske kompetencije; (3) organizacijske kompetencije; (4) sistemske kompetencije (saradnju s političkim i nevladinim institucijama); (5) razvojne i kompetencije za osobni napredak; (6) kompetencije vezane uz profesionalnu praksu (teorijska i metodološka znanja, poznavanje etičkog kodeksa, poznavanje kulturalnih specifičnosti te kreativnost $\mathrm{u}$ radu) 


\section{Komepetencije socijalnih pedagoga u odgojno-obrazovnim ustanovama}

Djelokrug rada socijalnog pedagoga u odgojno-obrazovnim ustanovama se kreće od ustanova predškolskog odgoja, redovnim osnovnim i srednjim školama pa do rada u đačkim domovima. Socijalni pedagozi kao stručni saradnici u predškolskim ustanovama imaju zadatak da razvijaju dosljednu politiku profesionalnog razvoja na razini ustanove. Prate Zakon o predškolskom odgoju i naobrazbi, pedagoške standarde i normative u ovoj oblasti. Osposobljeni su za: identifikaciju djece $\mathrm{s}$ poremećajima $\mathrm{u}$ ponašanju; izradu Programa prevencije poremećaja u ponašanju u predškolskim ustanovama; saradnju s drugim stručnim licima s kojima rade na tretmanu djece $s$ poremećajima $u$ ponašanju predškolske dobi. Djelokrug kompetencije je proširen i na rad s roditeljima djece s poremećajima ponašanja. Značajan doprinos daju u timskom radu sa stručnim saradnicima stručnih profila.

Kada je u pitanju stručni rad u osnovnim i srednjim školama socijalni pedagozi su zaposleni na mjestu stručnog suradnika te posjeduju sljedeće kompetencije: poznavanje i primjena Zakona o osnovnom i srednjem odgoju i obrazovanju, sudjelovanje u izradi godišnjih nastavnih planova, rad na izradi Prilagođenih nastavnih programa $i$ individualiziranih programa s djecom koja imaju poteškoće u razvoju kao i djecom koja imaju poremećaj u ponašanju. Mogu da rade na planiranju i programiranju saradnje s roditeljima, osposobljeni su za izradu Programa prevencije poremećaja u ponašanju, rade s roditeljima koji imaju djecu $\mathrm{s}$ poremećajem $\mathrm{u}$ ponašanju na modifikaciji poremećaja u ponašanju individualno i grupno, osposobljeni su da subjektivno i objektivno vrednuju rezultate rada, da vrše evaluaciju metoda objektivnog vrednovanja, sudjeluju u školi sa stručnim saradnicima stručnih profila u timskom radu s ciljem donošenja ključnih pitanja koja se tiču prevencije poremećaja u ponašanju kod učenika.

Specijalne osnovnoškolske ustanove i zavodi su mjesta gdje socijalni pedagozi rade, gdje polažu stručni ispit i stiču dodatne stručne kompetencije. Osim poznavanja Zakona o radu u osnovnim i srednjim specijalnim školama, socijalnih pedagozi se upoznaju sa specifičnim aspektima nastavnog plana i programa, planiranjem i programiranjem odgojno-obrazovnog rada djece sa MR, autizmom i poremećajima $u$ 
ponašanju. Sudjeluju u izradi Prilagođenog nastavnog programa, upoznaju se s problemom socijalne komunikacije djece te sudjeluju i planiranju u programiranju sadržaja za djecu s kombiniranim smetnjama. Zajedno $\mathrm{s}$ ostalim stručnim saradnicima rade na modifikaciji poremećaja u ponašanju kako individualno tako i grupno.

Način stažiranja socijalnog pedagoga definisan je pravilnicima o polaganju stručnih ispita, a jedan od njih koji se odnosi na pripravnički staž u zdravstvenim i socijalnim ustanovima u cijelosti prenosimo („Službene novine Tuzlanskog kantona", broj 2/09).

\section{PROGRAM PRIPRAVNIČKOG STAŽA ( UKUPNO 2 MJESECA)}

\section{Primarna zdravstvena zaštita (1 mjesec)}

Dio pripravničkog staža u okviru primarne zdravstvene zaštite kandidat će iskoristiti za evidentiranje i rano otkrivanje djece i omladine sa poremećajima u ponašanju

1.1. Dispanzer za nervne, duševne bolesti i toksikomanije

Upoznavanje sa Zakonom o zdravstvenoj zaštiti

Upoznavanje o vođenju evidencije bolesti ovisnosti (toksikomanija)

Upoznavanje sa formiranjem kartona ovisnika

Upoznavanje sa programiranjem tretmana ovisnika

\section{Sekundarna zdravstvena zaštita (1 mjesec)}

2.1. Klinika za duševne bolesti

Upoznavanje sa vođenjem stručne dokumentacije

Upoznavanje sa vođenjem evidencije

Upoznavanje sa djelokrugom rada socioterapijske zajednice

Upoznavanje sa provođenjem tretmana

Rad sa pojedincem

Rad u grupi

Rad u zajednici (komune) 


\section{PROGRAM PRIPRAVNIČKOG STAŽA U SOCIJALNIM USTANOVAMA (3 MJESECA)}

\section{Centar za socijalni rad ( 75 dana)}

- Upoznavanje sa Zakonom o socijalnoj zaštiti, zaštiti civilnih žrtava rata i zaštiti obitelji sa djecom

- Upoznavanje sa sistematizacijom poslova i radnih zadataka centra za socijalni rad i djelokrugom rada

Upoznavanje sa timskim radom stručnjaka u okviru centra za socijalni $\mathrm{rad}$

Komisija za identifikaciju, ocjenjivanje i razvrstavanje djece i omladine ometene u psihotjelesnom razvoju

Upoznavanje sa službom socijalne zaštite djece i mladih ometenih $u$ psihotjelesnom razvoju

Upoznavanje pravilnika o radu komisije

\section{Referat maloljetničke delikvencije}

Upoznavanje sa pisanjem izvještaja sucima i tužiteljstvu

Upoznavanje sa evidencijom maloljetnika

Upoznavanje sa sudskim raspravama

Upoznavanje sa odgojnim mjerama

Upoznavanje sa sprovođenjem odgojnih mjera

Rad sa školama, obiteljima, sredinom u kojoj maloljetnik živi

Sprovođenje preventivnih mjera

Individualni rad sa maloljetnikom

Upoznavanje sa grupnim radom

Upoznavanje sa timskim radom

\section{Ustanove posttretmanske zaštite (0,5 mjeseci)}

Upoznavanje sa ustanovama posttretmanske zaštite (klubovima, komunama, udruženjima)

Upoznavanje sa organizacijom i djelokrugom posttretmnanske zaštite 
Mjesto posttretmanske zaštite u sistemu interventnih mjera

Upoznavanje sa položajem pojedinca, pravima, obavezama i mogućnostima u okviru posttretmanske zaštite

Upoznavanje sa koordinacijom zdravstvenih i socijalnih službi i službi posttretmanske zaštite (centra za socijalni rad i dispanzera za duševne i nervne bolesti, klinike, komune, udruženja)

Upoznavanje sa načinom života u komuni i stručnim profilima koji provode posttretmansku zaštitu

U sklopu profesionalnog uobličavanja socijalnog pedagoga, moguće područje rada istog jeste i u policiji i kazneno-popravnim zavodima kako u okviru preventivnog tako i u okvirima reaktivnog odgovora na pojavu kriminaliteta. Plan pripravničkog staža socijalnog pedagoga obuhvata: Sektor kriminalističke policije; Odjel za narkomaniju; Odjel za prostituciju i Odjel za krvne delikte. U kazneno-popravnim institucijama socijalni pedagozi rade u odjeljenjima za osuđenike muškog i ženskog spola. Iako u BiH nije još uvijek regulisan položaj socijalnog pedagoga u policiji i kazneno-popravnom zavodu služit ćemo se primjerima iz susjedne Republike Hrvatske. Uporište rada socijalnih pedaoga u policiji Hrvatske nalazimo u Zakonu o sudovima za mladež, gdje se navodi da službenici moraju biti specijalizirani za poslove maloljetničkog kriminaliteta, što znači poznavanje maloljetnika u okvirima psiholoških, biopsiholoških, pedagoških i patoloških znanosti.

Posljednjih godina dolazi do pozitivnih promjena u zakonodavnoj praksi i sve više imamo slučajeva zapošljavanja socijalnih pedagoga, što otvara veće mogućnosti poštivanja prava i potreba djece, mladeži i njihovih obitelji, te savremeniju ponudu brojnih aktivnosti $\mathrm{i}$ intervencija u kojima socijalni pedagozi imaju ključnu ulogu.

\section{ZAKLJUČAK}

Kroz prikaz stogodišnjeg razvoja kocepta Socijelne pedagogije i elaboracijom prikaza brojnih teorija koje su etablirale njen dalji razvoj, Socijalna pedagogija se izdvojila kao naučna disciplina i profesija te istakla kao nepobitna u svom postojanju. 
Iz obima i djelokruga rada socijalnog pedagoga može se uočiti izražena interdisciplinarnost socijalnopedagoških profesionalnih kompetencija ovog poziva, koja je primjerena današnjem društvu i vremenu. Kratko rečeno, riječ je o pomagačkoj struci koja pomaže osobama kojima je neophodna pomoć i tretman u neželjenim vidovima ponašanja. Socijalni pedagog takvim ljudima pomaže da se uključe u društvo i vode što uspješniji život. Također, on sarađuju s roditeljima, učiteljima ili drugim odgajateljima. Socijalna pedagogija kao naučna disciplina treba da bude promovirana u $\mathrm{BiH}$. Ono što ide u prilog ovoj činjenici jesta da je prisutna ekspanzija socijalne pedagogije kao akademske discipline u evropskim državama. Ona svakako daje dobru podlogu za promišljanje daljnjeg razvoja socijalne pedagogije i na prostorima Bosne i Hercegovine. Vrijedi istaknuti značaj i razvoj odsjeka koji obrazuju kadar socijalnih pedagoga koji mogu biti krilatice napretka i sigurnosti funkcionalnog sistema u Bosni i Hercegovini. Naime, ulaganje u prevenciju i pronalaženje odgojnih i drugih metoda kojima je neželjeno ponašanje djece i mladih moguće usmjeriti prema drugim, društveno prihvatljivim i individualno konstruktivnijim modelima ponašanja, svakako doprinosi boljitku cijelog društva. Ciljano socijalno ulaganje u programe prevencije treba biti dio javne politike koja se temelji na univerzalnosti prava i povećanju jednakih prilika za sve. Da bi se to unaprijedilo, neophodna je saradnju između odgojnoobrazovnog sistema, sistema socijalne zaštite i zdravstvenog sistema kako bi detektiranje djece/učenika s poremećajem u ponašanju bilo sistemski riješeno što bi utjecalo i na razvoj sistema podrške u odgojnoobrazovnim i socijalnim ustanovama.

\section{LITERATURA}

1. Boehnisch, L. (1993) Sozialpaedagogik des Kindes- und Jugendalters, Juventa.

2. Bouillet, D. (2005) Kriminologija i socijalna integracija, Vol 13, Br. 1. 75-88.

3. Bouillet, D., Uzelac, S. (2007) Osnove socijalne pedagogije, Zagreb: Školska knjiga.

4. Engelke, E. (2002) Theorien der Sozialen Arbeit. Eine Einführung, Freiburg im Breisgau, 3. Auflage. 
5. European Bureau of International Association of Social Educators AIEJI (2005) A Common Platform for Social Educators in Europe. http://www.aieji.net, 15. aprila, 2005.

6. Europska komisija (2004) Ključne kompetencije za cjeloživotno učenje - europski re-ferentni okvir, http://ec.europa.eu/education/policies/2010/doc/basicframe.pd.

7. Hallstedt, P., Hogstrom, M. (2005) The reconceptualization of social pedagogy. A study of three curricula in the Netherlands, Norway and Ireland. Malmo: Holmbergs.

8. Hamalainen, J. \& Kurki, L. (1997) Sosiaalipedagogiikka. Juva: WSOY. [Social Pedagogy. Juva: WSOY.]

9. Hamalainen J. (2005) Socijalna pedagogija kao akademska disciplina u obitelji socijalnih znanosti: finski scenarij, Kriminologija i socijalna integracija. Vol. 13 (2005) Br.2. 87-91.

10. Jokić, B. (ur.) (2007) Ključne kompetencije učiti-kako-učiti i poduzetništvo u osnovnom školstvu Republike Hrvatske: sažeto izvješće o rezultatima projekta. Zagreb: Institut za društvena istraživanja.

11. Kobolt, A. (1997) Teorijske osnove socijalnopedagoških intervencija. Kriminologija i socijalna integracija, 5, 1-2, 129-140.

12. Kornbeck, J. (2013a) Transatlantic issues in social pedagogy: What the United Kingdom can learn from Iberoamerica. Scottish Journal of Residential Child Care, 12(1), 58-75.

13. Mikšaj-Todorović, Lj., Buđanovac, A. (1999) Socijalnopedagoški programi - uvjet za komunikaciju između struke i javnosti.

Kriminologija i socijalna integracija, 7, 1, 57- 64.

14. Niemeyer, Ch. (1998) Klassiker der Sozialpädagogik. Einführung in die Theoriegeschichte einer Wissenschaft. Weinheim / München.

15. Poldrugač, Z. (1999) Osvrt na programe izobrazbe socijalnih pedagoga u nekim europskim zemljama, Kriminologija i socijalna integracija, 7, 2, 189-195.

16. Previšić, V., Prgomet, A. (2007) Socijalno-pedagoške teorije u Njemačkoj tijekom 20. stoljeća. Pedagogijska istraživanja. 4, (1), 7-23. UDK 37.013.42(430)"19" Zagreb.

17. Schmidt, H.-L. (1981) Theorien der Sozialpädagogik. Kritische Bestandsaufnahme vorliegender Entwürfe und Konturen eines handlungsorientierten Neuansatzes. Rheinstetten.

18. Thiersch, H. (1996) Theorie der Sozialarbeit/Sozialpädagogik. In: Kreft, D., Mielenz, I. (Hrsg.), Wörterbuch Soziale Arbeit. 4. Auflage. Weinheim/Basel, 618-623. 
19. Tuggener, H. (1990) The Role of The Socialpedagogue - An Outline of A European Model, FICE International Bulletin, 3, 14-21.

20. Ucar, X. (2013) Exploring different perspectives of social pedagogy: towards a complex and integrated approach. Education policy analysis archives. Special Issues: Social Pedagogy in the 21st Century, 21,36, 119.

21. Uhlendorff, U (2012) Socijalna pedagogija u Njemačkoj, Kriminologija i socijalna integracija. Vol. 20 (2012) Br. 1, 1-13

22. Uhlendorff, U: Handbuch Erziehungswissenschaft (Hrsg.: Böhm,W. / Frost, U. / Ladenthin, V. / Mertens, G.), Band III, Teilbereich 6, Umwelten/ Sozialpädagogik (2008/2009).

23. Žižak, A. (2001) Razvoj socijalne pedagogije kao akademske discipline. Kriminologija

24. \& socijalna integracija. 9, (1), 61-70.

25. Winkler, M. (1993) Hat die Sozialpädagogik Klassiker? Neue praxis, 23 (3), 171-185. 


\author{
Dr. sc. Nusreta Kepeš, associate professor \\ University of Bihać \\ Islamic Pedagogical Faculty \\ Email:nusretakepes@yahoo.com
}

\title{
THE PLACE AND ROLE OF SOCIAL TEACHERS IN EDUCATIONAL AND SOCIAL WELFARE INSTITUTIONS
}

\section{Abstract}

New social circumstances, as well as the problems that society faces when it comes to children and youth with behavioral disorders, increasingly impose the need to investigate the causes of such behavior and elaborate socio-pedagogical interventions and offer models of social integration. The role of the social pedagogues in this issue is very important, especially in the field of diagnosis, prevention and treatment of behavioral disorders. In the EU countries, as well as in the countries in the region, the profession of social pedagogues has been recognized and included in the systematization of jobs in a large number of educational, social, penitentiary and health institutions. In Bosnia and Herzegovina, the situation is significantly different. Graduated social pedagogues, not only find it harder to find a job, but also have the problem of taking the professional exam, because the standards and norms of educational, social and health institutions rarely mention the social pedagogue as a professional associate. Recently, there have been positive changes, so now we can see the socialpedagogue employed in kindergartens, social work centers, health care institutions, communes, homes for the elderly, homes for children without parental care, extended stay in primary schools and as assistants in continue, with the obligation to take a pedagogical group of subjects. Although these are small advances, they are very significant in profiling this call. The faculties that educate this staff and associations of social pedagogues can make a great contribution in a way that students spend more practical hours in institutions during their studies, promote social and humane reputation of the profession and lobby the competent ministries to legally establish the profile of social pedagogue as a professional associate. education, social work, health and other state institutions. State policy can also affect the employment of this staff in public and state services, so it is important that in the creation of policies, laws, standards and norms as well as the systematization of jobs in various institutions, this profession is included. The entry of social pedagogues into teams and professional services will greatly contribute to the improvement of the situation in society, especially when it comes to violence against (and among) children and young people. Bearing in mind that social pedagogy in BiH is still in its infancy, a strong affirmation of this vocation is expected in the future, which has a helping character. This paper 
focuses on the application of the concept of social professional boundaries at the practical, as well as theoretical and scientific level of the discipline of social pedagogy.

Keywords: Social pedagogy, competencies of social pedagogues, pedagogical and social dimension of the profession of social pedagogues 
الدكتورة المشاركة السيدة نوسريتا كيبيش جامعة بيهاتش كلية التربية الإسلامية Email:nusretakepes@yahoo.com

\section{مكانة المربين الاجتماعيين ودورهم في مؤسسات التربية والتعليم ودور الرعاية الاجتماعية}

\section{الخلاصة}

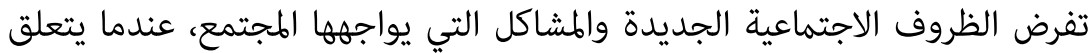

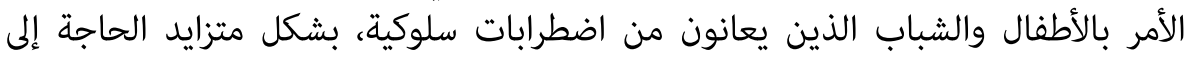

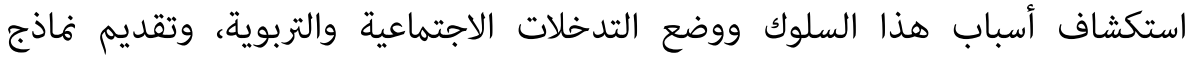

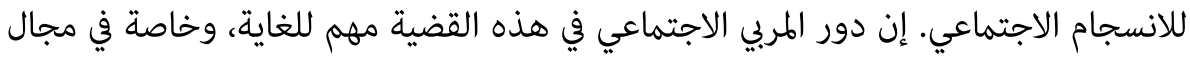

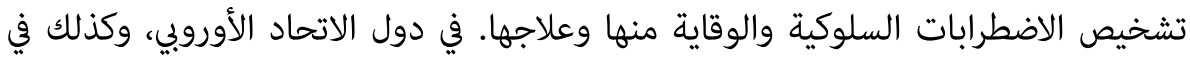

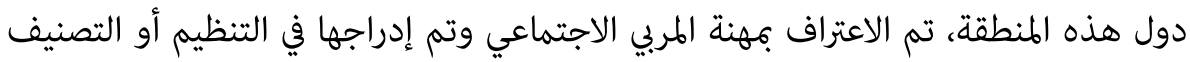

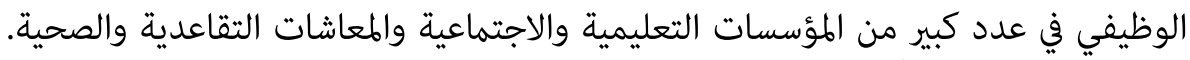

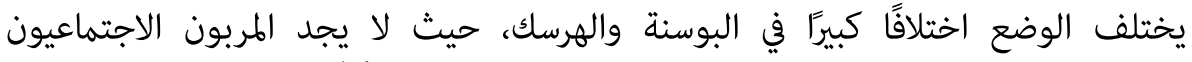

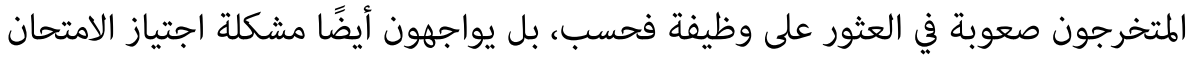

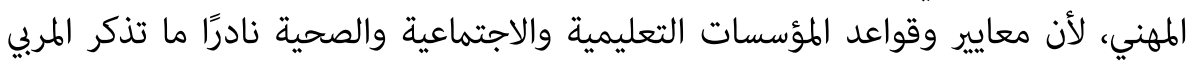

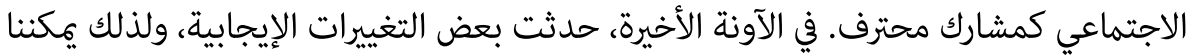

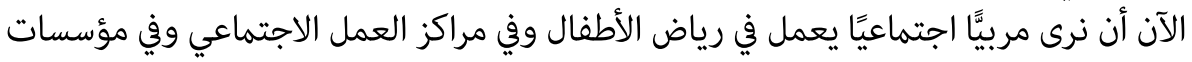

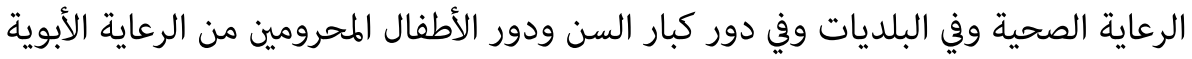

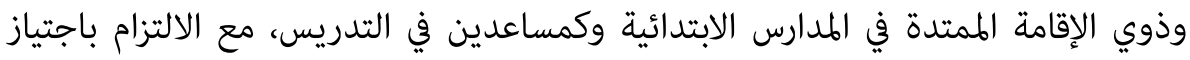

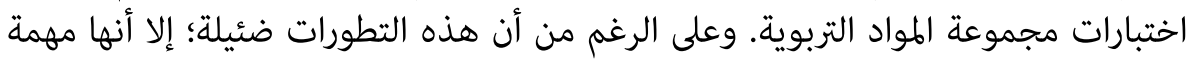

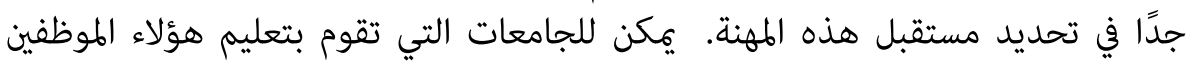

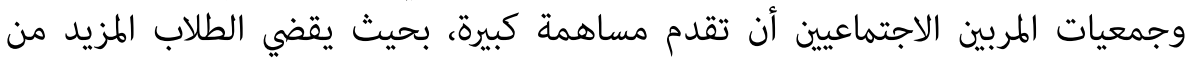

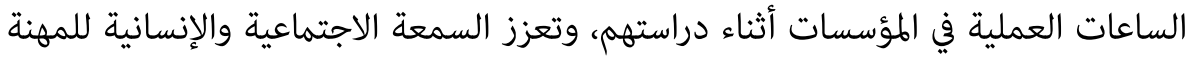

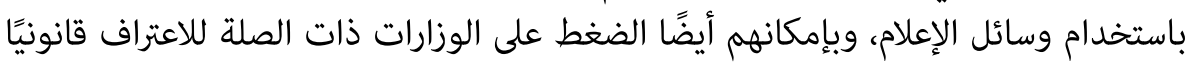

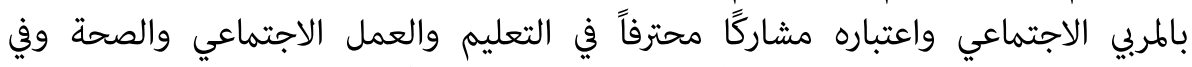

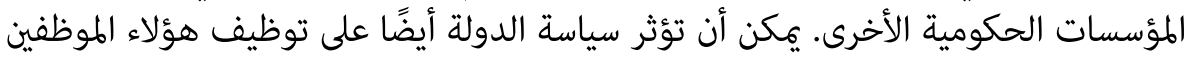

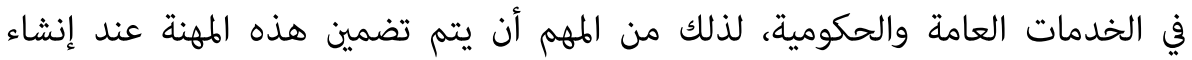

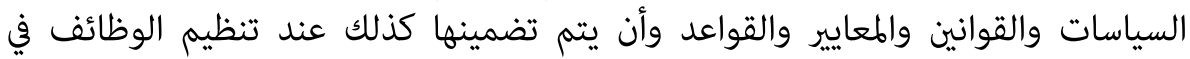

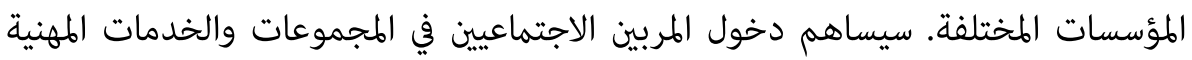


بشكل كبير في تحسين الوضع في المجتمع، لا سيما عندما يتعلق الأمر بالعنف ضد الأطفال

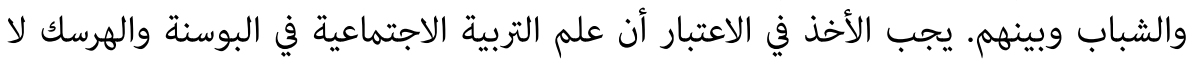

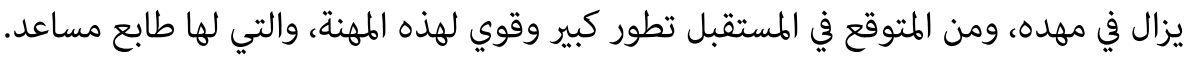
يركز هذا المقال على تطبيق مفهوم الحدود المهنية الاجتماعية، ويتطرق كذالك الكالى إلى القسم العملي والنظري والعلمي في مجال التربية الاجتماعية.

الكلمات المفتاحية: كفاءات المربين الاجتماعيين، التربية الاجتماعية، البعد التربوي والاجتماعي كهنة المربين الاجتماعيين. 